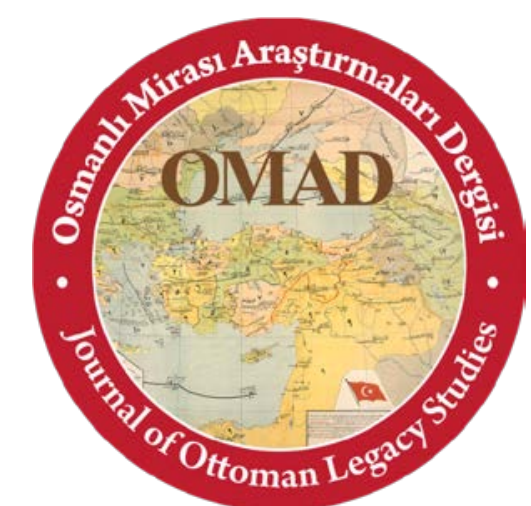

Osmanlı Mirası Araştırmaları Dergisi/Journal of Ottoman Legacy Studies

ISSN 2148-5704

www.osmanlimirasi.net

osmanlimirasi@gmail.com

Cilt 6, Sayı 15, Temmuz 2019 / Volume 6, Issue 15, July 2019

\title{
LEADERSHIP TRAITS OF SULEIMAN THE MAGNIFICIANT, IN TERMS OF "GREAT MAN" THEORY
}

Kanuni Sultan Süleyman'ın "Büyük Adam" Teorisi Bağlamında Sahip Olduğu Liderlik Özellikleri

\author{
Makale Türü/Article Types : Araştırma Makalesi/Research Article \\ Geliş Tarihi/Received Date : 05.04.2019 \\ Kabul Tarihi/Accepted Date : 30.06.2019 \\ Sayfa/Pages : 317-327 \\ DOI Numaras1/DOI Number : http://dx.doi.org/10.17822/omad.2019.128
}

\section{NILÜ̈ER RÜZGAR}

(Dr. Öğr. Üyesi), Bursa Teknik Üniversitesi, İnsan ve Toplum Bilimleri Fakültesi, İşletme Bölümü, Bursa / Türkiye, e-mail: nilufer.ruzgar@btu.edu.tr, ORCID: https:/ / orcid.org/00000002-9598-3390

\section{$\underline{\text { Atıf/Citation }}$}

Rüzgar, Nilüfer, "Leadership Traits of Suleiman The Magnificiant, In Terms Of "Great Man” Theory", Osmanlı Mirası Araştırmaları Dergisi [Journal of Ottoman Legacy Studies], 6/15, 2019, 317- 

Osmanlı Mirası Araştırmaları Dergisi (OMAD), Cilt 6, Sayı 15, Temmuz 2019.

Journal of Ottoman Legacy Studies (JOLS), Volume 6, Issue 15, July 2019.

ISSN: $2148-5704$

\title{
LEADERSHIP TRAITS OF SULEIMAN THE MAGNIFICIANT, IN TERMS OF “GREAT MAN” THEORY
}

\section{Kanuni Sultan Süleyman’ın “Büyük Adam”Teorisi Bağlamında Sahip Olduğu Liderlik Özellikleri}

\section{NILLÜFER RÜZGAR}

\begin{abstract}
Leadership theories has been widely researched throughout the history by researchers, scholars and authors. Great Man Theory, is accepted as the first product of these researches. According to the theory, great leaders are born, not created. They hold specific and distinctive characteristics/traits of leadership innately. In this sense, among the mighty figures in world history, the 10th emperor of the Ottoman Empire, Suleiman the Magnificient (Kanuni Sultan Süleyman/Muhteşem Süleyman), is one of these figures who is accepted as a Great Man. From this point of view, the aim of this study is to examine the leadership traits of Suleiman the Magnificient, in terms of Great Man Theory, by scrutinizing the literature about leadership and scholarly works of glorious Ottoman history.
\end{abstract}

Keywords: Great man, Leadership, Suleiman the Magnificient

Öz: Liderlik teorileri tarih boyunca araştırmacılar, sosyal bilimciler ve yazarlar tarafindan detaylıca araştııılmıştır. Büyük Adam Teorisi, bu araştırmaların ilk ürünlerinden biri olarak kabul edilmektedir. Teoriye göre lider olarak doğulur, sonradan lider olunmaz. Büyük adamlar, liderliğin ayırt edici özelliklerine doğuştan sahiptirler. $\mathrm{Bu}$ bağlamda, dünya tarihinin en güçlü figürleri arasında yer alan 10. Osmanlı Padişahı Kanuni Sultan Süleyman (Muhteşem Süleyman), "Büyük Adam” olarak kabul edilmektedir. Bu bakış açısından yola çıkarak hazırlanan bu çalıșmanın amacı, Kanuni Sultan Süleyman'ın liderlik özelliklerini Büyük Adam Teorisi bağlamında, liderlik literatürünü ve muhteşem Osmanlı tarihi hakkındaki çalışmaları derinlemesine araştırarak, incelemektir.

Anahtar kelimeler: Büyük adam, Liderlik, Kanuni Sultan Süleyman

\section{Introduction}

In leadership literature, the researchers/scholars seem to adapt two common views about leadership. The former view is that leaders are born ${ }^{1}$ and thus, their leadership qualifications are subconscious. ${ }^{2}$ The latter view is that people have to work hard to gain the specific leadership qualifications in order to "emerge" as leaders ${ }^{3}$. The "Great Man" theory ${ }^{4}$, which is the main motivation of this study, is a product of the former view that supports leadersip qualifications

\footnotetext{
${ }^{1}$ Keith Grinth, The Arts of Leadership, Oxford University Press, Oxford, 2000; Friedrich Nietzsche, The Will to Power, Vintage, New York, 1969.

${ }^{2}$ Alexander Lowen, Biogenetics, Penguin, New York, 1975.

${ }^{3}$ Mary Henrikson, "Great Leaders Are Made, Not Born: Conclusion of a Four-Part Series", AWHONN Lifelines, 10(6), (2006). pp./ 510-515; Andrew Kakabadse ve Nada Kakabadse, Essence of Leadership, International Thomson, London, 1999; Andrew Kakabadse ve Andrew Myers, "Boardroom Skills for Europe”, European Management Journal. 14(2), (1996). pp./ 189-200.

${ }^{4}$ Thomas Carlyle, On Heroes and Hero Worship and the Heroic in History, Whitefish, MT., Kessinger, 1841/2007; William James, “Great Men and their Environment”, Atlantic Monthly. 46(276), (1880). pp./ 441-459.
} 
are possessed intrinsically. ${ }^{5}$ According to the theory, when the qualifications are identified by other people, namely the followers, they gather around these "great men" and follow him. ${ }^{6}$

In the beginning of the XVI. century, after Yavuz Sultan Selim died in 1520, Ottoman Empire's power was at its highest extent, which was not seen in their history before. The empire reached almost the the same power with other world nations, in terms of both economy and military army. It was just Hungary, which was not conquered yet and there were only two empires that were able to conquer the country: Ottoman Empire and Germany-Spain. It was obvious that the conquerer, would become the superior of Europe, and thus, a world empire. Therefore the Ottomans were about to reach a glory, honor and grandeur that was not ever possible to another dynasty throughout the history when Suleiman the Magnificient came to throne. ${ }^{7}$

The acts that raise a nation to the top of its wealth and power, are the masterpieces of great men. ${ }^{8}$ In this sense, in the historical terms, it is seen that the famous rulers acted to enlive both the country and the people and thus, achieved the greatest rank among the other countries. The reign of Suleiman I., namely Suleiman the Magnificient, who was the 10th Sultan of Ottoman Empire, was the most important era of the Ottoman history. The empire owed all the might, conqurements, civilization, codes of law and architectural masterpieces, to this Sultan. $\mathrm{He}$ not only influenced his successores and predecesors, but also influenced the other rulers/emperors of other nations and inspired them to act like "Great Men", as he himself acted. He was known as "Lawgiver" (Kanunî), "Magnificient" and "Great" in all over the world. ${ }^{9}$ The purpose of this study, is to examine the leadership traits of Suleiman the Magnificient in terms of Great Man Theory. In this sense, a literature review is conducted to scrutinize the theory and history books are examined deeply.

\section{Importance of The Study}

There are a great number of studies on leadership theories, including Great Man Theory, in literature. There are also a great number of studies that give information about traits/characteristics of Ottoman Empires, including Suleiman the Magnificient. On the other hand, there is almost no study that examines leadership traits of Suleiman the Magnificient in terms of Great Man Theory. Therefore this study constitutes importance in terms of originality and it is expected to shed light on future researches and researchers.

\section{1. “Great Man” Theory In Leadership}

When the studies about leadership throughout the history are scrutinized, it is seen that the specific traits/qualifications of leaders are mentioned frequently. This interest about leadership is the result of the fact that leadership concept is considered as important in order to sustain success and wealth for humanity. For example, the masterpiece of Sun Tzu, The Art of War, draws attention to the importance of leadership. ${ }^{10}$ Wisdom, reliability, courage, determination, understanding people and giving value to people, are mentioned as among the most important leadership traits and it is underlined that each trait has a specific role. In Illiada and Odysseus of Homeros; fairness, wisdom, courage and virtuousness are mentioned as the most important traits of leadership. In addition, it was also believed that most of the mentioned traits are innate. ${ }^{11}$ Platon $^{12}$, in his masterpiece "State", suggests that wisdom, fairness,

\footnotetext{
${ }^{5}$ Kakabadse ve Kakabadse, Essence of Leadership.

${ }^{6}$ Isaac Mostovicz, Nada Kakabadse ve Andrew Kakabadse, “A Dynamic Theory of Leadership Development”, Leadership \& Organization Development Journal. 30(6), (2009). pp./ 563-576.

${ }^{7}$ Yılmaz Öztuna, Başlangıcından Zamanımıza Kadar Türkiye Tarihi. 5. Cilt, Hayat Yayınları, İstanbul, 1964.

${ }^{8}$ Joseph Von Hammer, Büyük Osmanlı Tarihi, İkra Yayınları, 1990.

${ }^{9}$ Von Hammer, 1990.

${ }^{10}$ Thomas Cleary, Sun Tzu - Savaş Sanatı, çev. Adil Demir, Kastaş Yayınevi, İstanbul, 2004.

${ }^{11}$ Bernard Sarachek, “Greek Concepts of Leadership”. The Academy of Management Journal. 11(1), 1968, pp./ 3948.
} 
virtuousness and taking care of both himself and others, are required traits for leadership. Aristotle, who was the best student of Platon, suggested that fairness, mildness, commonsense and endurance were among the four traits of leadership. ${ }^{13}$ In his study that gives infomation about Hun Turks Emperor Atilla, Wess ${ }^{14}$ mentions that courage, self-confidence, determination, resolution, responsibility and reliability are the traits that are hold by leaders and these traits become abilities through experience. Machiavelli ${ }^{15}$, who lived in Middle Era Europe, states in his masterpeace "The Prince" that a leader should be both wise and courageous.

The traits that are afore mentioned, in addition to the unmentioned ones, are the products of efforts to shape a leader. The Great Man Theory, constitutes the first written studies in leadership area. ${ }^{16}$

In the history of humanity, in all the masterpieces of distinguished people, there is the label of "pioneer", "rescuer", "hero". These "great men”, although they were present throughout the history, was first scrutinized by Thomas Carlyle in 1841, in his study "On Heroes", with a philosophical language. According to Carlyle, although the things that are seem perfect and ready-made, namely the material entities, they took their sources from the brains of "great men". He also suggests that the history of humanity is actually the history of great men and the socities are founded with the aim of worshipping to great men. ${ }^{17}$ Similarly, Ralph Waldo Emerson's work "Representative Man”, that was published in 1850 and Francis Galton's work "Hereditary Genius", that was published in 1869, examined "Great Men". Therefore these mentioned works and the other researches that are similar to them, gave pace to the thought of "Great Man” and theorized it. ${ }^{18}$

The founder of theory, as it is mentioned above, is Thomas Carlyle (1795-1881), who was born in Scotland in a period of crisis and upheaval, because of the Napoleonic wars and the accelerating pace of industrialization. Therefore, Carlyle looked for a source of strength, direction, wisdom, and uplift, which was not the Church anymore, according to him. ${ }^{19}$ Carlyle's search led him to the Great Man: an individual of this earth but unmistakably sent by God. At the time, he was already a well-known author and he started to become "the most widely read and the most greatly admired social philosopher of his time", with the theory "great man". ${ }^{20}$ Carlyle started his lectures and opened his series of London talks on "heroes" by explaining his intent: "We have undertaken to discourse here for a little on the Great Men, their manner of appearance in our world's business, how they have shaped themselves in the world's history, what ideas men found of them, what work they did on Heroes'. According to him, great men were sent by God to be heroes and these heroes became leaders through the righteous process of hero worship. Carlyle's great men were an eclectic groupthat consists prophets, poets, priests, men of letters, and kings. He thought that Shakespeare's characters showed the greatness of men. He also considered Oliver Cromwell and Martin Luther as great men, and this demonstrates that Carlyle's great men were heroic figures. ${ }^{21}$

According to the theory, as it is mentioned before, the capacity for leadership is inherent, which means that great leaders are born, not made. Therefore the theory depicts leaders as

\footnotetext{
${ }^{12}$ Platon (Eflatun), Devlet, çev.: Sabahattin Eyüboğlu ve M. Ali Cimcoz, İş Bankası Yayınları, İstanbul, 2006.

${ }^{13}$ John Adair, Inspiring Leadership - Learning from Great Leader, Thorogood Publishing Ltd., London, 2002.

${ }^{14}$ Roberts Wess, Leadership Secrets of Attila The Hun, Grand Central Publishing, 1989.

${ }^{15}$ Niccolo Machiavelli, Prens. çev: Nazım Güvenç, Anahtar Kitaplar Yayınevi, İstanbul, 1999).

${ }_{17}^{16}$ Bernard Bass, Bass \& Stogdill"s Handbook of Leadership, 3rd Edition. The Free Press, New York, 1990.

17 Rasim Adasal, Yeryüzü Tanrllarl, Liderler, Komutanlar ve Kahramanlar Psikolojisi, Minnetoğlu Yayınları, İstanbul, 1979.

${ }^{18}$ Faruk Şahin, "Büyük Adam Düşüncesġnden Liderlikte Özellikler Kuramına Kavramsal Bir Bakış", C.Ü. İktisadi ve Ídari Bilimler Dergisi. 2012, 13(1).

${ }^{19}$ Chris R. Vanden Bossche, Carlyle and the Search for Authority, Ohio State University Press, Colombus, 1991.

${ }^{20}$ Salwyn J. Schapiro, “Thomas Carlyle, Prophet of Fascism”, Journal of Modern History 17, 1945, pp./97-115.

${ }^{21}$ Bert Allan Spector, "Carlyle, Freud, and the Great Man Theory”, Leadership 2016, 12(2), 2015, pp./ 250-260.
} 
heroic and mythic. In this point, it would be important to draw attention to a fact, which is about the theory was named as great "man", not "woman". According to Ololube ${ }^{22}$, the reason of this is that, at that time, leadership, especially the military leadership, was thought of primarily as a male quality. ${ }^{23}$ Its basic premise is built on the fact that leadership is biologically determined, behaviourally demonstrated and innate to the male gender. ${ }^{24}$ Therefore, it can be said that both because of the mentioned reasons and the limited number of women in that era who occupied leadership positions, women were excluded from the theory. ${ }^{25}$

Early studies of leadership often focused on those who were already great leaders, such as Gandhi, Churchill, Jesus and Mohammad. These are examples of great men that influenced their erat $\mathrm{o}$ a great extent. Frequently, great leaders came from the aristocracy because the lower and middle class were rarely given opportunities to lead. This caused some early researchers to suggest that breeding had something to do with leadership. ${ }^{26}$

As stated by Bass \& Bass ${ }^{27}$, "Without Moses, the Jews would have remained in Egypt; without Winston Churchill, the British would have given up in 1940; without Bill Gates, there would have been no firm like Microsoft”. Therefore, from these mentioned leaders, who are considered as great, and the many others, it can be concluded that the great men hold such innate traits that they become able to affect fate of the world.

To sum up, the leaders that are considered as "great men"; were rescuers, pioneers, heores in their times. These leaders emerged in times when it was needed to satisfy needs, which were shaped by social, economical and moral feelings. These leaders, because of their strong characteristics and personalities, showed a superior talent to lead the societies. Therefore it is also important to mention that, according to the theory these leaders who hold the certain superior traits, should have mutual agreement with the group or society, that is in need of something. ${ }^{28}$ According to some authors, the evolution of the societies have happenned thanks to the great men who have prompted the societies with their acts. ${ }^{29}$

The thoughts that reject "great man" theory, on the other hand, were put forward by Hegel and Fichte in XVIII. and XIX. centuries. According to this thought, which is called "Zeitgeist", originally, the big leaders are not the architects of big changes. They are just the people that emerge to "fill the gaps", whichemerge because of the era's problems. Therefore, according to Zeitgeist, situational factors are the creators of leaders. However, the capability of "great men" to gather people around them and put influence on them, can only be explained by

22 Nwachukwu Prince Ololube, Educational Management, Planning and Supervision: Model for Effective Implementation, Spring Field Publishers, Owerri, 2013.

${ }^{23}$ Euriel C. Uzohue, Japheth A. Yaya ve Oluseyi A. Akintayo, “A Review of Leadership Theories, Principles, Styles and their Relevance to Management of Health Science Libraries in Nigeria”, Journal of Educational Leadership and Policy, 1(1), 2016, pp./ 17-26.

${ }^{24}$ Steven H. Appelbaum, Linda Audet ve Joanne C. Miller, “Gender and leadership? Leadership and gender? A journey through the landscape of theories”, Leadership \& Organization Development Journal, 24(1), 2003, pp./4351.

${ }^{25}$ Christian Harrison, “Leadership Research and Theory”, Leadership Theory and Research, 2018, p./18.

${ }^{26}$ Helen L. Eckmann, “Great Man Theory: A personal account of attraction”, Paper For The IBA Conference, National University, San Diego, n.d.

27 Bernard M. Bass ve Ruth Bass, The Bass Handbook of Leadership: Theory, Research, and Managerial Applications (4th ed.), Free Press, New York, 2009.

${ }^{28}$ Adasal, Yeryüzü Tanrllarl, Liderler, Komutanlar ve Kahramanlar Psikolojisi, 1979.

${ }^{29}$ Adair, Inspiring Leadership - Learning from Great Leader, 2002; Adasal, Yeryüzü Tanrllarl, Liderler, Komutanlar ve Kahramanlar Psikolojisi, 1979. 
really difficult traits that are gained later and which are not innate. ${ }^{30}$ As time passed the "great man" theory is replaced by "traits theory", while Zeitgeist is replaced by "situational theory". ${ }^{31}$

\section{The Leadership Traits Of Suleiman The Magnificient (1520-1566), In Terms Of His Character And Heroic Victories}

Suleiman I., who was known with his justice and therefore named as "Lawgiver" (Kanuni), was born in Trabzon, in 1495. His father is Yavuz Sultan Selim, the 9th Sultan of Ottoman Empire, and his mother was Hafize Sultan, the daughter of Kırım Khan Devletgiray. When he was the governor of Trabzon Sanjak (Sancak Beyi), his father and his grandfather Sultan Bayezit, paid great attention to his education. ${ }^{32}$

In Eastern culture, there is the belief that in the beginning of each century a great man appears and starts to dominate the world. In their culture there is also a belief that the number " 10 " is holly. Among the numbers, which were presented by Pisagor, Number " 10 ", is the perfect one. This is because of the fact the sequence of numbers ends with 10 and it is necessary to start from the first number in order to count again. In addition to this, there are 10 fingers in both hands and feet and there are also 10 senses (explicit and implicit). The "aşer" in (kuraât-1 aşere), Tevrat's "Evâmir-i Aşere" (Ten Commands), "Aşere-i Mübeşşere" (10 people that are announced to goto heaven), military cathegorization as 10 -"Corporal" (Onbaş1), "Captain" (Yüzbaşı) and "Major" (Binbaşı)-, semâvât-1 aşere (10 skies) ukûl-i aşere (According to Aristo cathegorization, the 10 levels of the mind), are other examples of this belief.Suleiman I., who was born in the first year of the 10th century (Hijri calender) and became the 10th emperor of Ottomans, was considered to be a hero, a great man and a magnificient person, from birth. Therefore he appeared on the history stage as such a strong figure that he was able to compete with all world leaders. ${ }^{33}$

When Suleiman Prophet (B.C. 970-931) sent a letter to Saba Queen (Melike) Belkıs via the letter carrier (nâme-ber/mektup götürücü) named Hüdhüd, he used the "Innehû nün Süleymâne ve innehû bismillanlrrahmânirra-hiym"; which is mentioned in the Nemi verse of the Koran (Ku'ran-1 Kerim). This verse was repeated in all the correspondences in the era of Kanuni Sultan Suleiman. ${ }^{34}$ Therefore this can be considered as another proof of the holliness and greatness of Suleiman the Magnificent, the 10th emperor of the Ottoman Empire.

All the necessary qualifications and capabilities in order to raise the Ottomans to the top of its history by using wars, laws and politics, were given to Sultan Suleiman by God, from birth. Until his era, the mentioned qualifications and capabilities were distributed to the previous emperors. One of them was a warrior, one of them was a real father, one of them law maker, one of them conquerer, one of them was regulator of the emperor's military. But it was not seen that all these traits were gathered to shape a great man, in one individual. It was Suleiman the Magnificient who gathered all these traits and capabilities in his character, as a great man.

Suleiman the Magnificient came to throne upon the death of his father, without competing anyone andwithout any intrigues, at the age of 22. His courtesy and humbleness was apperant on his young face. He had the face of a ruler, and looked older than he was, because of his serious-mindness. An Ottoman poet, who had the chance of living with him at the same era, depicts him as : "His forehead was broad, his nose was like a beak, his mouth was dignified, his chins were round. He had serious eyes, which did not constitute any threat and shadowed with

\footnotetext{
${ }^{30}$ Edgar F. Borgatta, Robert F. Bales ve Arthur Couch, "Some Findings Relevant To the Great Man Theory of Leadership”, American Sociological Review, 19(6), 1954, pp./755-759.

31 Naim Işık, "İnsan Kaynakları Liderlik Yaklaşımları Ve Hizmetkâr Liderliğin İşgörenlerin Organizasyonel Bağlılıklarına Etkileri” (doktora tezi), İstanbul T.C. Bahçeşehir Üniversitesi Sosyal Bilimler Enstitüsü, 2014.

32 Osmanlı Padişahları, (İstanbul: Veb Ofset), (Günaydın'ın Okurlarına Armağanı).

${ }^{33}$ Von Hammer, Büyük Osmanlı Tarihi, 1990.

${ }^{34}$ Von Hammer, Büyük Osmanlı Tarihi, 1990.
} 
long and black eyelashes". He could use the sword, arrow and horse as perfect as a Turcoman Governor (Türkmen Beyi). His appearance, was construed in the correspondences of foreign ambassadors and the portraits of Venetian painters. His soul could be seen from his physical appearance. He was full of innate capabilities, virtue, humbleness, interest for the good and the nice and courage that is harmonized with justice and awe-inspiring appearance. When he was in Saruhan, away from Istanbul, in the era of his father Yavuz Sultan Selim, and when he was responsible for the empire when Sultan Selim was in İran Military Expedition, he gained necessary traits to become an emperor and he also learned about the palace intrigues, which made him experinced enough when he became the emperor of the Ottoman Empire. In addition, he gained the capability of knowing and selecting people at a very young age. ${ }^{35}$

The first year of Suleiman the Magnificient as the emperor of the Ottoman Empire, was both in peace and glory at wars, which constituted an example for the upcoming years. He never took his attention away from the state works. In each act, he showed the traits of a great man, traits of a great emperor and the moral values of a perfect Muslim. He always sticked to the Islamic rules and procedures in his decisions and he was such a great man that he was also a protector of science, scientists, art and artists. ${ }^{36}$

As it is afore mentioned, when he came to the throne, the Ottoman Empire was experiencing its the most magnificient era, thanks to Yavuz Sultan Selim. The first issues that were taken into consideration by Suleiman the Magnificient were the problems in running the state, which occured because of the vast expansion of the empire's borders. In his 2nd year on the throne, he decided to start a Military Expedition to Hungary, which was experiencing a chaos in itself. He passed to Rumeli with his army and conquered Belgrad Castel, to include it in empire's borders. After his victory in Europe, he continued to Rodos Island in Aegean Sea. After sieging the island, which was the pirate centre of Christianism, with around 300 ships, he conquered the island after 6 months battle. After all these glories Suleiman the Magnificient decided to pay attention to the interior issues of the empire and he did successful attempts, which proved that he was a magnificient ruler and a great man. At the time, he accepted the help need of French King François I., who was defeated by German King Charles V, and helped this important European country. In 1526, Hungary became a country that created problems for the empire. In order to put an end to this situation, he decided to start a battle with Hungary with an army of 300.000 soldiers. The Ottoman Army met Hungarian Army in Mohaç Plain. In this very big and bloody war, which was called as "Mohaç Major Battle" (Mohaç Meydan Muharebesi), he defeated Hungary. Upon winning the battle, the capital city of Hungary, Budin became an Ottoman city. Suleiman the Magnificient entered Budin with a great ceremony and stayed there in order to arrange the public works. He also sent some important pieces of art to Istanbul. He appointed Transilvania Governoras Hungarian King and then he returned to Istanbul, the center of the Ottoman Empire. The fact that the Ottoman Empire proceeded to the middle of the Europe, made some European countries worried and nervous. Therefore the King of Austria, with the support of other European countries, started a military expedition to Hungary King, who was under the command of the Ottoman Empire and they conquered Budin. In addition, he sent some messengers to Sultan Suleiman in order to demand the other Hungarian cities back. But Sultan Suleiman got really angry about this demand and he kept messengers as prisoners in Istanbul for 9 months. After, in spring he started another military expedition to Hungary with an army of 250.000 soldiers. When he arrived at Mohaç, he accepted the Hungary King and let him kiss his hand (as a display of respect). Then he proceeded to Pest (Peşte) and conquered both cities again. But Sultan Suleiman's anger was so serious that he wanted to give a lesson to the King of Austria and he passed Hungary to arrive in front of Vienna. He sieged Vienna, the capital city of Austria, for a very long time. However, he could not be able to continue the siege

\footnotetext{
${ }^{35}$ Alphonse De Lamartine, Cihan Hâkimiyeti. (Tercüman, 1001 Temel Eser, n.d.).

${ }^{36}$ Joseph Von Hammer, Osmanlı Tarihi. Devlet-i Aliye, Kamer Yayınları, İstanbul, 2017).
} 
anymore, because of the harsh weather conditions in winter and returned to Istanbul. Although the expected results could not be gained from the siege of Vienna, the fact that the Ottoman Army arrived in front of Vienna without any obstacles, was a source of fear for the rulers of European countries. Therefore they agreed on forgetting the disputes among each other and coming together as one great power to defeat the Ottomans. Emperor Charles V., was appointed as the leader of this European force. In 1532, Suleiman the Magnificient decided to start a battle with Charles V. with an army of 250 thousand soldiers in order to prove him his undefeatable power. In this military expedition, which was called "German Expedition", a number of castles and cities are conquered and new victories are gained. Although Sultan Suleiman sent messengers to Charles V., to say that he and his army was waiting for him to fight, Charles V. felt really afraid and did not accept the battle. Therefore, with his new and great victories, Suleiman the Magnificient returned to Istanbul with his mighty army. This victory was celebrated in Istanbul for days and nights. When Sultan Suleiman was about to start a military expedition to Iran, the King of Austria sent messengers and wanted peace. Sultan Suleyman agreed on this, on the condition that Austria did not bleach the agreement. ${ }^{37}$

As for the Iran expedition, after Tahmasap, the son of Shah Ismail, conquered Tebriz back, which had been conquered by Yavuz Sultan Selim, Sultan Suleiman wanted to arrange a military expedition and get back Tebriz. He proceeded to Eastern Anatolia with his big and great army and conquered Tebriz in addition to Azerbaijan. Then he proceeded to the South and conquered Baghdad, which was the most famous and the most important city of Mesopotamia.

Sultan Suleiman, not only gave importance to his land military army but also aimed at reaching a great glory in the world seas. Therefore he did everything, spent all effort to develop naval forces, armada. He assigned Barbaros Hayrettin Pasha as the captain pasha of the armada. Barbaros Hayrettin, proved that he was a great pasha immediately by defeating famous Andrea Doria in sea battles and shaped Mediterranian as an Ottoman Lake. They did not let any sea men to act in Red Sea and Indian Ocean. After all these glories both on the land and on the seas, because of some chaos in Hungary, Sultan Suleiman decided to arrange a new military expedition to there. But unfortunately he became sick on the way and he died around Zigetvar, just after the castle is conquered by the Ottoman Empire. In order to hinder a chaos to emerge in the army, his death was kept as a secret for some time. His corpse was brought to Istanbul and he was buried in the tomb of Suleymaniye Mosque. He was 70 years old when he died and he was the emperor who was on the throne for the longest time, when compared to the other Ottoman Emperors. ${ }^{38}$

"None of the princes had been educated as Suleiman the Magnificient, the son of Yavuz Sultan Selim, and none of the emperors ruled empire as practically as he did". "Si "Suleyman the Magnificient, never let any action that would harm to the state. He was also smart enough to comprehend the real intentions of the people that talked to him and gave his answers accordingly". ${ }^{40}$ According to Hammer translator Hellert, who was a conservative French, depicted Suleiman the Magnificient as: "The only ruler in the history of New Era that can be compared to Suleiman the Magnificient, is Louis XIV." ${ }^{41}$, although it was obvious that Sultan Suleiman was superior to Louis XIV.

Sultan Suleiman was a scholar in areas such as literature and law. He could talk in Arabic, Serbian and Persian. ${ }^{42}$ He was also a great poet. The most famous strophes of him are as follows:

\footnotetext{
${ }^{37}$ Osmanlı Padişahlarl, n.a., 1988.

${ }^{38}$ Osmanlı Padişahları, n.a., 1988.

${ }^{39}$ Sydney N. Fisher, The Middle East, A History, New York, 1959.

40 İsmail Hakkı Uzunçarşı11, Osmanlı Tarihi, 2. Cilt, Türk Tarih Kurumu, Ankara, 2011.

${ }^{41}$ Von Hammer, Büyük Osmanlı Tarihi, 1990.

${ }^{42}$ Von Hammer, Büyük Osmanlı Tarihi, 1990.
} 
"Olmaya devlet cihanda bir nefes sihhat gibi.

Saltanat dedikleri bir cihan gavgaasıdır.

Olamaya baht u sa'adet dünyede vahdet gibi”.

(Breathing and being healthy, are the most important strengths of people.

Reigning is a world war.

Being together, is the most happiest thing.)

As for the laws that he applied, which caused him to be called as "Kanuni" (Lawgiver), instead of applying exactly the same basic law that was made by Fatih the Conquerer, KaanunName, he created a new law of fundemental organization based on Fatih's Kaanun-Name. Sultan Suleiman were considered to be among the most important law makers in the world because of the law of fundamental organization. Even his effigy was put in the congress gallery of Washington. ${ }^{43}$

Sultan Suleiman was also taking care of the women and children and he enacted all traditions, habits, customs, provisions and tolerances, by taking the family concept as base, in order to protect them. Getting married became both a national and a religious duty in order to increase the population. The husbands were responsible for satisfying the needs of their wives in terms of food, housing and security. In addition, the husbands were obliged to let their wives to see their family members or relatives at least once in a week. In order to prevent women to face with their husbands caprices or aspertions, divorce rules were based on strong foundations. According to Kur'an-1 Kerim: "The men who divorce their wives without any logical reason, will be damned by Allah". A divorced woman had the right to keep and raise her children. The state would also adopt the deserted children and feed and educate them in the name of the society. The law always protected them. According to a provision in the law: "Who finds a child in front of the door of a mosque or hamam, on the street, have to take him to his home and show necessary care. If he adopts that child, he holds all the rights about the child. If he does not want to adopt the child, the state takes the responsibility of raising that child". ${ }^{44}$

Sultan Suleiman, served Istanbul in many ways. Suleymaniye Complex (complex of buildings adjacent to a mosque), Sultan Selim Mosque that he got built for his dad Yavuz Sultan Selim, the mosques for his sons and lots of pieces of Islamic art for Mihrimah Sultan, Hürrem Sultan and Haseki Sultan, made Istanbul an Islamic capital city. 40 wells canals (Kırk Çeşme Suyolları), Büyük Çekmece Bridge, İmam-1 Azam Ebu Hanife and Şeyh Abdülkadir Gilani Complexes in Baghdad, extensions to the Mevlana Celaleddini Rumi Complex in Baghdad, Seyyid Battal Gazi Complex, mosques and schools in Damascus (Şam) and Çoban Mustafa Pasha Bridge on Meriç River, are some distinctive examples of the Islamic pieces of art that are built in the era of Suleiman the Magnificient. In addition to these, the walls of Jerusalem, repairement of Kâbe and the canals of Mekke are again the products of the reign of Sultan Suleiman. The empire reached the widest borders in his era. As afore mentioned, he supported science and arts. Kemalpashazade, Ebussuud Efendi, Celalzade Salih Çelebi, Taşköprülüzade İsameddin Ahmet, Kınalızade Alaeddin Ali Çelebi, Ahteri Mustafa bin Şemseddin, Erdebilli Zahirüddin, Şebüsterli Abdullah bin Şeyh İbrahim, Halepli Muhammed bin İbrahim, Kazvinli Ahmed bin Abdülavval, Karabağlı Muhyiddin Muhammed, Mustafa bin Muhammed (Bostan Çelebi) and Fevri Ahmet, were among the scholars, poets and religious men that he supported. He used the name "Muhibbi" when writing his poems. He published his Divan (classical Ottoman poetry). It is known that he married to 4 women. The first wife of Sultan Suleiman was the mother of prince Mahmut, the second wife was Mah-i Devran, the mother of prince Mustafa, the third one was Gülfem Hatun, the mother of prince Murat and the 4th and the last wife of

\footnotetext{
${ }^{43}$ Öztuna, Başlangıcından Zamanımıza Kadar Türkiye Tarihi, 1964.

${ }^{44}$ Alphonse De Lamartine, Osmanlı Tarihi, Kapı Yayınları, İstanbul, 2008.
} 
Sultan Suleiman was Hürrem Sultan, the daughter of an Orthodox priest from Ukraine and the mother of prince Selim. ${ }^{45}$

\section{Conclusion}

The oldest approach towards leadership researches, is the "Great Man Theory". The theory goes back to Ancient Greek times ${ }^{46}$. Among the supporters of the theory, Heredot and Tacitus, focused on big leaders and tried to unreveal the traits that differentiated them from the others. The common point of view of the supporters of the theory, is that in order to become a great leader, some traits should be possessed by birth. The great men, influence people and have power on them. According to Thomas Carlyle's Great Man Theory, history of humanity is shaped by the great men who possess certain and specific gifts from God, by birth. These traits are impossible to gain later by experience ${ }^{47}$.

Suleiman the Magnificient, the 10th Emperor of the Ottoman Empire, was among the greatest men in the world history. As it is mentioned in the previous section, he possessed the necessary traits by birth, which helped him to raise the Ottoman Empire to the top. Until his era, those necessary traits were distributed to the previous emperors. One of them was a warrior, one of them law maker, one of them conquerer and one of them was regulator of the emperor's military. But it was not seen that all these traits were gathered to shape a great man, in one individual. It was Suleiman the Magnificient who gathered all these traits and capabilities in his character, as a great man. In addition, he always sticked to the Islamic rules and procedures in his decisions. Therefore it can be said that he was aware of the gifts that were given by Allah and thus, he acted as a perfect Muslim.

As it can be comprehended from the literature review, Suleiman the Magnificient had all the traits that were necessary to be a "great man". Therefore it can be said that he suits the theory. In academic literature, there is a lack of such researches. Especially the Ottoman Empire with its magnificient emperors and victories, constitutes great importance and the leadership traits are worth to examine deeply.

\section{Bibliography}

Adair, John, Inspiring Leadership - Learning from Great Leader. London: Thorogood Publishing Ltd. 2002.

Adasal, Rasim, Yeryüzü Tanrlarl, Liderler, Komutanlar ve Kahramanlar Psikolojisi. İstanbul: Minnetoğlu Yayınları. 1979.

Appelbaum, Steven H., Audet, Linda, \& Miller, Joanne C., “Gender and leadership? Leadership and gender? A journey through the landscape of theories". Leadership \& Organization Development Journal, 24(1). (2003). 43-51.

Aslan, Şebnem, "Karizmatik Liderlik ve Organizasyonel Vatandaşlık Davranışı İlişkisi: Kurumda Çalışma Yı1ı ve Ücret Değişkenlerinin Rolü”. Uluslararası İnsan Bilimleri Dergisi. 6 (1). (2009).

Bass, Bernard M., Bass, Ruth, The Bass Handbook of Leadership: Theory, Research, and Managerial Applications (4th ed.). New York: Free Press. 2009.

\footnotetext{
${ }^{45}$ Mehmet Akif Erdoğru, Osmanlı Tarihi, İlya Yayınevi, İzmir, 2012.

${ }^{46}$ Michael A. Hogg ve Graham M. Vaughan, Social Psychology, 7th Ed., Pearson, London, 2006.

${ }^{47}$ Halil Can, Organizasyon ve Yönetim, (Ankara: Siyasal Kitabevi, 2005); Şebnem Aslan, "Karizmatik Liderlik ve Organizasyonel Vatandaşlık Davranışı İlişkisi: Kurumda Çalışma Yıılı ve Ücret Değişkenlerinin Rolü", Uluslararası İnsan Bilimleri Dergisi, 6 (1), 2009.
} 
Bass, Bernard M., Bass \& Stogdill"s Handbook of Leadership. 3rd Edition. New York: The Free Press. 1990.

Borgatta, Edgar F., Bales, Robert F., Couch, Arthur S., "Some Findings Relevant To the Great Man Theory of Leadership”. American Sociological Review, 19(6). (1954). 755-759.

Bossche Chris R. Vanden, Carlyle and the Search for Authority. Columbus: Ohio State University Press. 1991.

Can, Halil, Organizasyon ve Yönetim. Ankara: Siyasal Kitabevi. 2005.

Carlyle, Thomas, On Heroes and Hero Worship and the Heroic in History. Kessinger, Whitefish, MT. 1841/2007.

Cleary, Thomas, Sun Tzu - Savaş Sanatı, çev. Adil Demir, İstanbul: Kastaş Yayınevi. 2004.

De Lamartine, Alphonse, Cihan Hâkimiyeti. Tercüman, 1001 Temel Eser. (n.d.).

De Lamartine, Alphonse, Osmanlı Tarihi. İstanbul: Kapı Yayınları. 2008.

Eckmann, Helen L., “Great Man Theory: A personal account of attraction”. Paper For The IBA Conference, National University, San Diego. (n.d.).

Erdoğru, Mehmet Akif, Osmanlı Tarihi. İzmir: İlya Yayınevi. 2012.

Fisher, Sydney Nettleton, The Middle East, A History. New York. 1959.

Grint, Keith, The Arts of Leadership. Oxford: Oxford University Press. 2000.

Harrison, Christian, "Leadership Research and Theory". Leadership Theory and Research, (2018). p.18. https://doi.org/10.1007/978-3-319-68672-1_2

Henrikson, Mary, "Great Leaders are made, Not Born: Conclusion of a Four-Part Series". AWHONN Lifelines, 10(6). (2006). pp. 510-515.

Hogg, Michael A., Vaughan, Graham M., Social Psychology. 7th Ed. London: Pearson. 2006.

Işık, Naim, Insan Kaynakları Liderlik Yaklaşımları Ve Hizmetkâr Liderliğin Işsgörenlerin Organizasyonel Bağlılıklarına Etkileri. (Yüksek Lisans Tezi). İstanbul: T.C. Bahçeşehir Üniversitesi Sosyal Bilimler Enstitüsü, 2014.

James, William, “Great Men and their Environment”. Atlantic Monthly.46(276). (1880). pp. 441-459.

Kakabadse, Andrew P., Kakabadse, Nada, Essence of Leadership. London: International Thomson. 1999.

Kakabadse, Andrew P., Myers, Andrew, Boardroom Skills for Europe. European Management Journal. 14(2). (1996). pp. 189-200.

Lowen, Alexander, Biogenetics. New York: Penguin. 1975.

Machiavelli, Niccolo, Prens. çev: Nazım Güvenç, İstanbul: Anahtar Kitaplar Yayınevi. 1999

Mostovicz, Isaac, Kakabadse, Nada K., Kakabadse, Andrew P., “A Dynamic Theory of Leadership Development”. Leadership \& Organization Development Journal. 30(6). (2009). pp. 563-576.

Nietzsche, Friedrich, The Will to Power. New York: Vintage. 1969.

Ololube, Nwachukwu Prince, Educational Management, Planningand Supervision: Model for Effective Implementation. Owerri: Spring Field Publishers. 2013.

Osmanlı Padişahlarl, İstanbul: Veb Ofset. (Günaydın'ın Okurlarına Armağanı). 
Öztuna, Yılmaz, Başlangıcından Zamanımıza Kadar Türkiye Tarihi. 5. Cilt. İstanbul: Hayat Yayınları. 1964.

Öztuna, Yılmaz, Başlangıcından Zamanımıza Kadar Türkiye Tarihi. 6. Cilt. İstanbul: Hayat Yayınları. 1965.

Platon (Eflatun), Devlet, çev.: Sabahattin Eyüboğlu ve M. Ali Cimcoz, İstanbul: İş Bankası Yayınları. 2006.

Roberts, Wess, Hun Imparatoru Atilla'nın Liderlik Strları, çev.: Yakut Eren, İstanbul: İlgi Yayınc1lik. 1989.

Sarachek, Bernard, “Greek Concepts of Leadership”. The Academy of Management Journal. 11(1). (1968). pp.39-48.

Schapiro J. Salwyn, “Thomas Carlyle, Prophet of Fascism”. Journal of Modern History 17. (1945). 97-115.

Spector, Bert Alan, “Carlyle, Freud, and the Great Man Theory”. Leadership 2016. 12(2). (2015). 250-260. DOI: 10.1177/1742715015571392

Şahin, Faruk, "Büyük Adam Düşüncesinden Liderlikte Özellikler Kuramına Kavramsal Bir Bakış”. C.Ü. Íktisadi ve İdari Bilimler Dergisi. (2012). 13(1).

Uzohue, Euriel C., Yaya, Japheth A., Akintayo, Oluseyi A., “A Review of Leadership Theories, Principles, Styles and their Relevance to Management of Health Science Libraries in Nigeria”. Journal of Educational Leadership and Policy. 1(1). (2016). pp. 1726.http://www.aiscience.org/journal/jelp

Uzunçarşı11, İsmail Hakkı, Osmanlı Tarihi. 2. Cilt. Ankara: Türk Tarih Kurumu. 2011.

Von Hammer, Joseph, Büyük Osmanlı Tarihi. İkra Yayınları. 1990.

Von Hammer, Joseph, Osmanl Tarihi. Devlet-i Aliye. İstanbul: Kamer Yayınları. 2017.

Wess, Roberts, Leadership Secrets of Attila The Hun. Grand Central Publishing. 1989. 